\title{
Trophic structure of the macrobenthic community of Hornsund, Spitsbergen, based on the determination of stable carbon and nitrogen isotopic signatures
}

\author{
A. Sokołowski $\cdot$ A. Szczepańska $\cdot$ P. Richard · \\ M. Kędra $\cdot$ M. Wołowicz $\cdot$ J. M. Węsławski
}

Received: 6 June 2013/Revised: 29 April 2014/Accepted: 8 May 2014/Published online: 21 May 2014

(C) The Author(s) 2014. This article is published with open access at Springerlink.com

\begin{abstract}
Hornsund is a cold-water fjord in southwestern Spitsbergen, Svalbard Archipelago, with a resident biota that exhibit typical low-temperature Arctic features. Carbon $\left(\delta^{13} \mathrm{C}\right)$ and nitrogen $\left(\delta^{15} \mathrm{~N}\right)$ isotopic signatures of macrobenthic fauna and its potential food sources were measured in summer 2008 to delineate the trophic structure of the bottom community and to identify its principal carbon sources. The soft-bottom fauna at a water depth of $100 \mathrm{~m}$ was found to rely primarily on detritus, which is supplied by sedimentation of suspended organic matter from the water column and horizontal transport of refractory macroalgae from euphotic coastal habitats. Through resuspension by bottom currents, deposited particles also contributed to the diet of benthic filter-feeders. Since benthic organisms were significantly enriched in ${ }^{13} \mathrm{C}$ compared to epibenthic zooplankton (mainly amphipods and decapods), the stable carbon signature provides a tool to differentiate benthic and pelagic feeding habits. The benthic food web was characterized by a conventional trophic structure with decreasing species numbers in increasing trophic levels. Primary consumers feeding on a mixture of plant matter, fecal pellets, decaying animal tissue, bacteria, and protists accounted for the greatest
\end{abstract}

\footnotetext{
A. Sokołowski $(\bowtie) \cdot$ A. Szczepańska · M. Wołowicz Institute of Oceanography, University of Gdańsk, Al. Piłsudskiego 46, 81-378 Gdynia, Poland e-mail: oceas@univ.gda.pl

P. Richard

Littoral, Environnement et Sociétés, UMR 7266 CNRS-

Université de La Rochelle, 2 rue Olympe de Gouges,

$17000 \mathrm{La}$ Rochelle, France

M. Kędra · J. M. Węsławski

Institute of Oceanology, Polish Academy of Sciences,

ul. Powstańców Warszawy 55, 81-712 Sopot, Poland
}

biomass share (62\% of the total macrobenthic biomass), followed by secondary consumers $(38 \%)$. Based on $\delta^{15} \mathrm{~N}$ signatures, three trophic levels were detected, corresponding to the following feeding guilds: filter-feeders and feeding generalists (mainly bivalves, crustaceans, polychaetes, and some fish), mixed detritivore-carnivores (polychaetes, priapulids, crustaceans, and ophiuroids) and obligate carnivores (ascidians). The average food chain length (4.5 trophic levels) suggests that high-quality food is readily available in this Arctic fjord ecosystem.

Keywords Trophic links - Food web - Stable isotopes · Benthic community $\cdot$ Hornsund $\cdot$ Spitsbergen

\section{Introduction}

Trophic relationships in marine and estuarine systems of the sub-Arctic and Arctic have been the subject of increasing interest, primarily in order to (1) evaluate the transport of energy and matter, fluxes, and cycles (the socalled flow approach); (2) identify species and feeding links that are most influential in the dynamics of community composition and structure (the so-called processfunctional approach); and (3) define potential contaminant transfer along the food chain and biomagnification (Horton et al. 2009; Iken et al. 2010; Renaud et al. 2011). The elucidation of the first two trophic functions in the Arctic has recently become an urgent issue, since this northern hemisphere sector is considered particularly vulnerable to the potential effects of global changes such as climate warming and biological invasions (ACIA 2004; Węsławski et al. 2009, 2011). There is general agreement that Arctic waters are currently in a transition toward a warmer state (Polyakov et al. 2005; Hop et al. 2006; Steele et al. 2008; 
Polyakov et al. 2010), and this trend is expected to continue (IPCC 2000).

The likely consequences of these alterations for the structure of Arctic ecosystems are not fully understood, but some biological changes have been linked to the effects of warming and abrupt hydrographic events (e.g., Hop et al. 2006; Węsławski et al. 2006, 2009, 2011). For example, recent extension of the distribution range of the blue mussel Mytilus edulis to the west coast of the Svalbard archipelago was shown to result from the unusually high northward mass transport of warm Atlantic water (Berge et al. 2005). The presence of three non-indigenous euphausiid species of typically Atlantic origin in Kongsfjorden (western Spitsbergen) has also been linked to enhanced Atlantic water inflow (Buchholz et al. 2010). From their extensive survey of long time-series data Węsławski et al. (2009) concluded that the advanced propagation of warmer low-latitude waters with the North Atlantic Current to the high European Arctic may be expected to cause a general increase in the overall biodiversity of Arctic biocenoses.

Alterations in the composition and abundance of pelagic and benthic species are likely to affect the organization of trophic interactions and the energy flows in the Arctic ecosystem (e.g., available resource use, energy transport in the food chain) (Aanes et al. 2002). Little information is available, however, on the direct implications of community shifts and changes in species composition on food web architecture in both the short and long term. The observed anomalies in the structure of biocenoses mostly concern primary and secondary consumers, including invertebrate herbivore-detritivores and carnivores, which occupy the second and third trophic levels. These low trophic level impacts can have cascading ecological effects on higher trophic level organisms such as seabirds and marine mammals (bottom-up) by decreasing the density of prey species. Under conditions of raised water temperature and the retreat of sea ice, a shift to short-lived and opportunistic surface-burrowing taxa in the benthic realm is expected due to lower sediment stability (Renaud et al. 2008). Together with simultaneous invasions of small-bodied organisms of lower energy reserves with the Atlantic waters, a substantial reduction in food resources to benthic consumers of higher trophic levels such as walrus and diving birds is anticipated (Węsławski et al. 2009). Climate-driven changes in the high Arctic ecosystem may also exert an inverse, top-down effect on the food web. In the Bering Sea, an increase in fish predation on benthic amphipods has been proposed as the cause of a decrease in the density of benthic crustaceans, which are the principal prey of migrating gray whales (Coyle et al. 2007). A similar topdown regulation was also observed in the Antarctic. It has been suggested that recent invasion of the west Antarctic
Peninsula by the predatory lithodid king crab Neolithodes yaldwyni has substantially reduced benthic megafaunal diversity and the local echinoderm population (Smith et al. 2012). Trophic relations can therefore provide a context for the management of living resources locally or on a wider scale (e.g., fishery management) and underlie the high heuristic value that food web interactions have for both ecological theory and practical measures.

This study was performed in order to describe the trophic relationships and principal energy pathways within benthic communities in Hornsund, an Arctic fjord in southwestern Spitsbergen, using stable isotopes of carbon and nitrogen. The main food sources supporting the softbottom benthic community were defined based on dual stable isotope ratios. In addition, feeding habits and the trophic position of macrofaunal species in the food web were assessed to characterize the hierarchical structure of the trophic pyramid. The results of this study also provide a benchmark against which future food web research will be able to trace alterations in coastal ecosystems of the high Arctic resulting from environmental changes.

\section{Materials and methods}

\section{Field collection}

Hornsund is an open fjord (30 km long, 12-15 km wide, without a sill at the entrance) on the southwest part of Spitsbergen island $\left(77^{\circ} \mathrm{N} 16^{\circ} \mathrm{E}\right)$ that is under the strong influence of the cold Sørkapp Current carrying Arctic waters from the eastern part of the archipelago (temperature range from -1.5 to $1.0^{\circ} \mathrm{C}$ and salinity from 34.3 to 34.8), and the resident biota exhibit typical low-temperature Arctic features. Intrusions of Atlantic waters from the West Spitsbergen Current (an arm of the North Atlantic Current) carrying relatively warm water (temperature often $>5^{\circ} \mathrm{C}$ and salinity $>34.7$ in the upper 100 -m-thick layer; Piechura et al. 2001) are occasionally observed. These two water masses are usually separated by a hydrological front (Arctic front) outside the fjord (Swerpel 1985; Węsławski et al. 1991). The colder water masses easily penetrate the fjord through a wide opening as a surface stream which spreads over the warmer and more saline Atlantic waters. Close to the glaciers in the inner parts of the fjord, freshwater runoff from melting ice causes strong vertical salinity and temperature stratification of the water column but this thermosaline gradient diminishes toward the fjord mouth (Swerpel 1985).

Macrobenthic fauna $(>1.0 \mathrm{~mm})$, epibenthic zooplankton (mainly amphipods and decapods; Węsławski personal communication), surface sediments, and the water column were sampled from the research vessel "Oceania" at the 
Fig. 1 Location of sampling sites in Hornsund, Spitsbergen

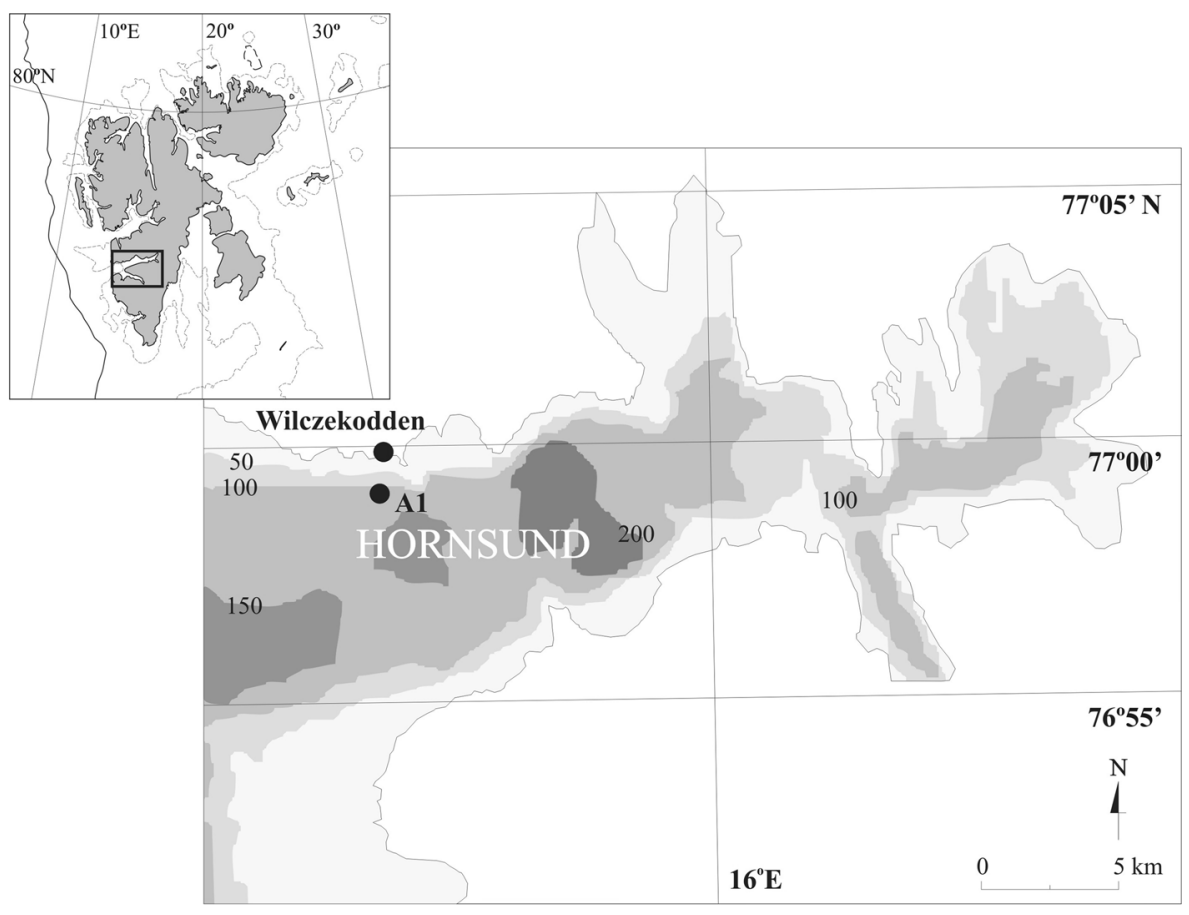

entrance of Hornsund (site A1; $\varphi 76^{\circ} 59.013 \mathrm{~N} \lambda$ $15^{\circ} 24.831 \mathrm{E}$ ) (Fig. 1) at a depth of $100 \mathrm{~m}$ on July 25, 2008, i.e., after the spring bloom when sea ice was not present. Surface sediments in this area are composed of very fine muddy deposits (Grzelak and Kotwicki 2012) of low total organic matter content (ca. 2.1\%; Schettler and Szczuciński unpubl. data). Prior to sampling, hydrological parameters of the overlying bottom water (salinity, temperature) were recorded during a standard conductivity, temperature, and depth (CTD) cast. The macrobenthos was collected in triplicate with a Van Veen grab $\left(0.1 \mathrm{~m}^{2}\right.$ catch surface area) and by dredging with a rectangular bottom dredge $(30 \times 50 \mathrm{~cm}$ and $1 \mathrm{~mm}$ internal mesh size $)$ which was pulled over a distance of ca. $700 \mathrm{~m}$. Samples were then sieved onboard through a $0.5-\mathrm{mm}$ mesh. Live animals were kept in Whatman GF/F-filtered sea water (glass microfiber filters; $0.7 \mu \mathrm{m})$ at the ambient environmental temperature and salinity ( $T=2.0^{\circ} \mathrm{C}$ and $\left.S=34.2\right)$ for around $12 \mathrm{~h}$ to purge. The organisms were cleaned of their epibionts and debris, identified to species level while alive (except the genus Ampharete) by examination under a stereomicroscope, rinsed with distilled water, and frozen at $-20^{\circ} \mathrm{C}$ for subsequent analyses. Stones carrying colonies of epibenthic bryozoans were frozen whole. Samples of epibenthic and pelagic zooplankton were obtained by towing a $180-\mu \mathrm{m}$ WP2 zooplankton net (Hydrobios, ring diameter $57 \mathrm{~cm}, 0.25 \mathrm{~m}^{2}$ ) five times from $3 \mathrm{~m}$ to approximately $20 \mathrm{~m}$ above the sea floor. Live planktonic animals were held in GF/F-filtered seawater (collected in situ) for $12 \mathrm{~h}$ to evacuate their gut contents, then sorted, and identified taxonomically before freezing at $-20{ }^{\circ} \mathrm{C}$. Samples of surface $(0-10 \mathrm{~m})$ and overlying bottom water (ca. $5 \mathrm{~m}$ above the sea floor) were taken by means of a $5-\mathrm{dm}^{3} \mathrm{GoFlo}$ Niskin water sampler. Within $1 \mathrm{~h}$ of collection, the water was passed through a $180-\mu \mathrm{m}$ net to remove larger zooplankton, then through precombusted Whatman GF/D filters (glass microfibre filters; $2.7 \mu \mathrm{m}$ ) to collect smaller zooplankton (fraction 180-2.7 $\mu \mathrm{m}$ ) and finally through precombusted GF/F filters (fraction 2.7-0.7 $\mu \mathrm{m}$ ) under moderate vacuum using a standard filtration system. Following filtration, the filters were rinsed with distilled water and frozen in individual polystyrene Petri dishes at $-20{ }^{\circ} \mathrm{C}$. The filtered water was filtered again through $\mathrm{GF} / \mathrm{F}$ filters, and these were used as blanks for isotope analysis. Due to the adverse meteorological conditions, seston was collected in one replicate per size fraction and water layer. Surface sediments were sampled in triplicate with a Van Veen grab, and the upper 5-cm-thick layer of undisturbed sediments was taken using a syringe and stored in dense polyethylene bags at $-20{ }^{\circ} \mathrm{C}$. The top $5 \mathrm{~cm}$ of the sediment represents the fraction that most benthic invertebrates can penetrate and is the biologically relevant portion.

In addition, as a potential supplementary carbon source for soft-bottom macrofauna, dominant benthic macroalgae (Fucus serratus, Laminaria spp., Chorda tomentosa, Acrosiphonia flagellata) were sampled in triplicate by hand during emersion from the intertidal zone in the coastal area (site Wilczekodden; Fig. 1), which is located in the direct vicinity of site A1 (distance of ca. $3.3 \mathrm{~km}$ ). Plants were rinsed with distilled water, cleaned of all visible 
incrustation and epiphytes using a tooth brush, identified to the lowest possible taxonomic level, and frozen in plastic bags at $-20{ }^{\circ} \mathrm{C}$.

\section{Stable isotope analyses}

Filters, sediments and benthic organisms were freeze-dried and acidified with $0.5 \mathrm{M} \mathrm{HCl}$ prior to the preparation of samples for isotope analysis. Bryozoans were identified to species level under a microscope and scrubbed off the stone surface. Carbonate carbon is often more enriched in ${ }^{13} \mathrm{C}$ than organic carbon in the marine environment, and this may confound isotopic analyses (Boutton 1991). Therefore, filters were acid-fumed (concentrated $\mathrm{HCl}$ ) for $3-4 \mathrm{~h}$ in a desiccator and allowed to dry overnight at $20{ }^{\circ} \mathrm{C}$ under a chemical fume hood (Jacob et al. 2005). The topmost surface, containing seston, was gently scrubbed off the filters with a scalpel, taking special care to avoid collecting glass material that is known to affect the conversion of organic carbon to $\mathrm{CO}_{2}$ during combustion (Boutton 1991). Sediment samples were homogenized in a standard mortar and pestle and dry-sieved through a $63-\mu \mathrm{m}$ polypropylene mesh to compensate for grain size effects on stable isotope analysis (Jianhua et al. 2008). Aliquots of approximately $150 \mathrm{mg}$ were then acidified with $1 \mathrm{M} \mathrm{HCl}$ and homogenized in an ultrasonic bath for $5 \mathrm{~min}$ to remove $\mathrm{CO}_{2}$. To prevent any loss of dissolved organic compounds, these samples were not rinsed, but were dried overnight at $50{ }^{\circ} \mathrm{C}$ in an acid digestion fume hood to evaporate the acid. After drying, the sediment was mixed with Milli-Q water, freeze-dried, and homogenized again to a fine powder. Animals with an external shell, such as bivalves and gastropods, were dissected using Teflon or polypropylene instruments. Whole organisms or individual soft tissues (bivalves and gastropods) of the same species/genus were grouped into three pools containing at least three (more for most species) individuals in order to obtain a representative sample. Prior to analyses, benthic plants and animals were ground to a fine powder. Samples that required acidification (i.e., macroalgae, bivalves, gastropods, and crustaceans) were acid-fumed $(1 \mathrm{M} \mathrm{HCl})$ overnight and then dried for $12 \mathrm{~h}$ in a dry bath under a filtered air flux at $60{ }^{\circ} \mathrm{C}$ to evaporate the $\mathrm{HCl}$.

The carbon $\left({ }^{13} \mathrm{C} /{ }^{12} \mathrm{C}\right)$ and nitrogen $\left({ }^{15} \mathrm{~N} /{ }^{14} \mathrm{~N}\right)$ isotopic ratios were determined in suspended particulate organic matter (SPOM), sediment detritus (SOM; all organic matter $<63 \mu \mathrm{m}$ including plant matter, fecal pellets, decaying animal tissue, bacteria, and protists), macrobenthic plants and animals, and zooplankton using a continuous-flow isotope-ratio mass spectrometer (Delta V Advantage, Thermo Scientific, Germany) coupled to an elemental analyzer (Flash EA1112 Thermo Scientific, Italy) that provides simultaneous data on carbon and nitrogen content
(C/N ratio was calculated for SPOM, SOM and macroalgae). The results are expressed relative to Vienna PeeDee Belemnite and atmospheric $\mathrm{N}_{2}$ for $\delta^{13} \mathrm{C}$ and $\delta^{15} \mathrm{~N}$, respectively, in the standard $\delta$ unit notation (\%) according to the following formula:

$\delta=\left[\left(R_{\text {sample }} / R_{\text {standard }}\right)-1\right] 10^{3}$,

where $R={ }^{13} \mathrm{C} /{ }^{12} \mathrm{C}$ for carbon, $R={ }^{15} \mathrm{~N} /{ }^{14} \mathrm{~N}$ for nitrogen, and $R_{\text {standard }}$ is the value for the reference material. Precision, calculated on the basis of replicate analyses of the standards (analytical error; SD), was $\pm 0.1 \%$ for both carbon and nitrogen. Because nitrogen stable isotope $\left(\delta^{15} \mathrm{~N}\right)$ values provide an indication of the trophic position of a consumer in the food web, the relative trophic level (RTL) was estimated for each faunal species, using the model developed by Hobson and Welch (1992):

$\mathrm{RTL}=\left(\delta^{15} \mathrm{~N}_{\text {consumer }}-\delta^{15} \mathrm{~N}_{\text {baseline }}\right) / 3.4+2$,

where $\delta^{15} \mathrm{~N}_{\text {consumer }}$ is the nitrogen isotope ratio of a consumer, $\delta^{15} \mathrm{~N}_{\text {baseline }}$ is the nitrogen isotope baseline, and 3.4 is assumed to be the ${ }^{15} \mathrm{~N}$ trophic enrichment factor (Olive et al. 2003). The nitrogen isotope baseline was calculated as the mean $\delta^{15} \mathrm{~N}$ of all primary consumers, since they show lower temporal variability than primary organic matter sources. Although employing a uniform baseline for different feeding guilds (herbivores, suspension-feeders, detritivores, etc.) is considered a simplification of complex feeding preferences, this approach is commonly applied for aquatic food webs (Vander Zanden and Fetzer 2007). The calculated error in the trophic position of an individual consumer due to source-specific baseline variation is generally low (ca. 0.2 trophic positions; Vander Zanden and Rasmussen 2001). The formula is a simplified modification of the food web model of Post (2002) and allows for the contribution of various organic matter sources in the diet of consumers, although the derived estimates are rather rough. RTL values of between 2 and 3 indicate the second trophic level (primary consumers and omnivores) while RTLs of $>3$ indicate consumers with carnivorous diets (secondary-, tertiary-, and higher-level consumers). In addition, total food chain length $(F C L)$ was calculated as the maximal RTL, following the definition of Duffy et al. (2007).

\section{Statistical analyses}

To define trophic groups of macrobenthic species, hierarchical cluster analysis of Bray-Curtis dissimilarities was performed using the stable isotope results of faunal taxa with Ward's minimum variance method of double-roottransformed $\delta^{13} \mathrm{C}$ and $\delta^{15} \mathrm{~N}$ (Davenport and Bax 2002). Due to the non-normal distribution (Shapiro-Wilk test for 
Fig. 2 Transformation of organic matter and its stable carbon and nitrogen isotope ratios in the outer part of Hornsund. Data for macroalgae and SOM are presented as the mean \pm 1 standard deviation $(n=3)$. SPOM, suspended particulate organic matter, SOM, sediment detritus. D and $\mathrm{F}$ denote the $180-2.7$ and $0.7-2.7 \mu \mathrm{m}$ SPOM size fractions, respectively, in surface and overlying bottom waters

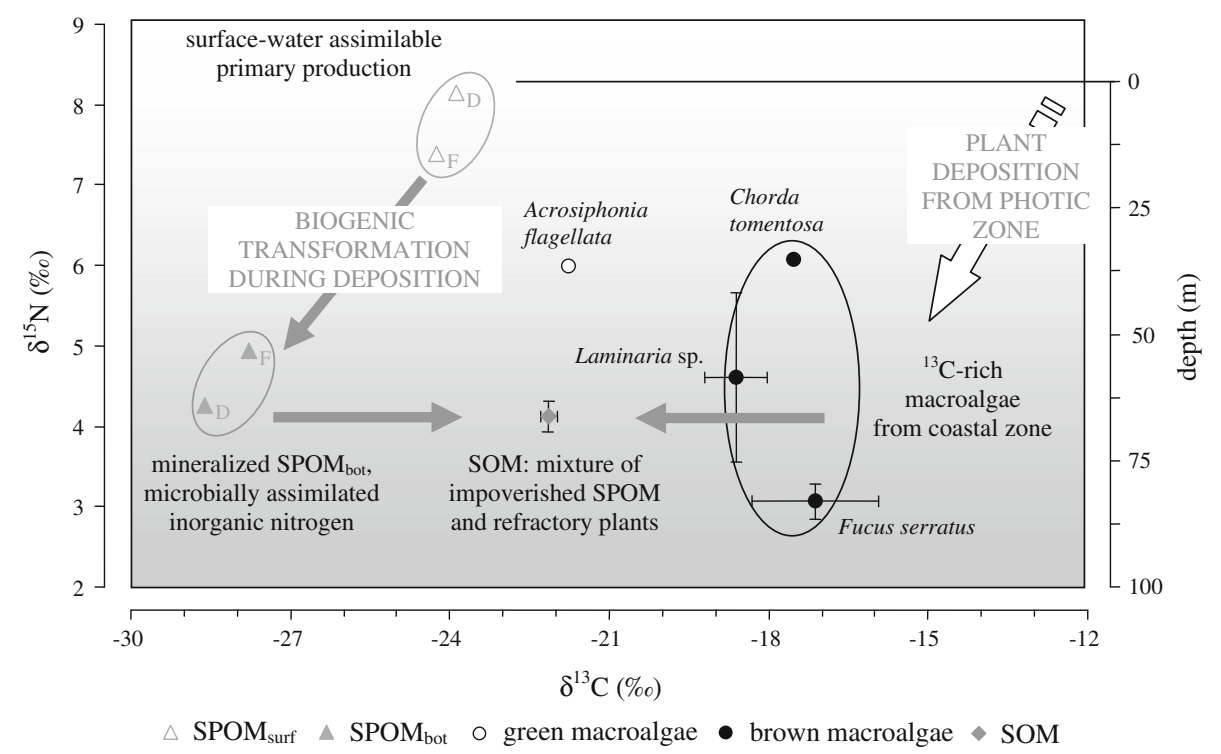

goodness of fit) and non-homogenous variances (Bartlett's test) in most data, a nonparametric approach was used in the statistical analysis. The significance of individual differences between two data groups was determined using the Mann-Whitney $U$ test. The level of significance was set at $p<0.05$. Analyses were performed using STATISTICA version 9.1 (Statsoft Inc., USA).

\section{Results}

Stable isotope ratios of potential carbon sources

Stable isotope ratios of potential carbon sources varied greatly among different components: $\delta^{13} \mathrm{C}$ spanned a range of $11.3 \%$ and $\delta^{15} \mathrm{~N}$ spanned a range of $5.1 \%$ (Fig. 2). SPOM differed statistically from SOM in carbon isotope ratios (Mann-Whitney $U$ test: $Z=-2.12, p<0.05$ ), but not in nitrogen isotope ratios (Mann-Whitney $U$ test). The $\delta^{13} \mathrm{C}$ of green and brown macroalgae collected from the coastal area was significantly different from that of SPOM (Mann-Whitney $U$ test: $Z=-2.91, p<0.004$ ) and SOM (Mann-Whitney $U$ test: $Z=-2.60, p<0.01$ ), with the macrophytes being more enriched in ${ }^{13} \mathrm{C}$, which allowed distinction of autochthonous macrobenthic vegetation as a separate source of organic matter. In addition, SPOM differed markedly in separate layers of the water column: Surface water $\mathrm{SPOM}_{\text {surf }}$ had more enriched isotope ratios for carbon and nitrogen than $\mathrm{SPOM}_{\mathrm{bot}}$ in the overlying bottom water. Suspended particulate organic matter in surface water also had a lower $\mathrm{C} / \mathrm{N}$ ratio (5.8-6.0) than that over the sea floor (6.5-7.9). Sediment detritus, SOM, the third carbon source in the benthic system, showed depleted $\delta^{15} \mathrm{~N}(4.3 \pm 0.2 \%)$, intermediate $\delta^{13} \mathrm{C}(-22.1 \pm 0.2 \%$ ), and an elevated $\mathrm{C} / \mathrm{N}$ ratio $(10.2 \pm 0.5)$.

Isotopic composition of fauna

Forty-eight faunal species, including six pelagic species taken with a WP2 zooplankton net (i.e., Pagurus pubescens, zoea, Calanus finmarchicus, Sagitta spp., Sarsia tubulosa, Halitholus cirratus, and Clione limacina) and 42 taxa sampled with a Van Veen grab and a bottom dredge, grouped into eight phyla were analyzed for stable isotope composition (Table 1). Detailed data on the abundance and biomass of macrobenthic organisms at the site examined in this investigation were obtained in a quantitative field study performed in the previous year (July 2007) by the Institute of Oceanology, Polish Academy of Sciences (Kędra unpublished data). The availability of these data permitted calculation of the percentage contribution of the number, abundance, and biomass of taxa that were collected for stable isotope analysis relative to the respective values of taxa that were sampled quantitatively at the same site. The species sampled for isotopic measurements represented $35.8 \%$ of species richness, which corresponds to 49.8 and $92.6 \%$ of the total macrobenthic abundance and biomass, respectively.

The $\delta^{13} \mathrm{C}$ and $\delta^{15} \mathrm{~N}$ of macrofauna in Hornsund spanned similar ranges of $7.5 \%$ (from $-25.0 \pm 0.0 \%$ for the pelagic calanoid $C$. finmarchicus to $-17.5 \pm 0.0 \%$ for the sedentary polychaete Travisia forbesii) and $8.5 \%$ (from $5.9 \pm 0.0 \%$ for the barnacle Balanus balanus to $14.4 \pm 0.0 \%$ for the ascidian Ascidia prunum), respectively (Table 1). Most zooplanktonic crustaceans (i.e., C. finmarchicus and $P$. pubescens, zoea), a gastropod 
Table 1 Stable nitrogen and carbon isotope ratios (\%), C/N ratios (for SPOM, SOM, and macroalgae) and carbon contents (gC $\mathrm{g}^{-1} \mathrm{dry}$ wt) of food web components and the corresponding relative trophic level (RTL, $\delta^{15} \mathrm{~N}$ baseline $=6.0 \%$ )

\begin{tabular}{|c|c|c|c|c|c|c|}
\hline Component/taxonomic group & $\delta^{13} \mathrm{C}$ & $\delta^{15} \mathrm{~N}$ & C/N, RTL & C content & Feeding mode & Reference \\
\hline $\operatorname{SPOM}_{\text {bot }}(180-2.7 \mu \mathrm{m})$ & $-28.5^{*}$ & 4.3 & 7.9 & & & \\
\hline $\operatorname{SPOM}_{\mathrm{bot}}(2.7-0.7 \mu \mathrm{m})$ & $-27.7 *$ & 5.0 & 6.5 & & & \\
\hline $\operatorname{SPOM}_{\text {surf }}(180-2.7 \mu \mathrm{m})$ & $-23.8^{*}$ & 8.2 & 5.8 & & & \\
\hline $\operatorname{SPOM}_{\text {surf }}(2.7-0.7 \mu \mathrm{m})$ & $-24.2^{*}$ & 7.4 & 6.0 & & & \\
\hline $\mathrm{SOM}<63 \mu \mathrm{m}$ & $-22.1 \pm 0.2$ & $4.1 \pm 0.2$ & $10.2 \pm 0.5$ & & & \\
\hline \multicolumn{7}{|l|}{ Division CHLOROPHYTA } \\
\hline \multicolumn{7}{|l|}{ Class Ulvophyceae } \\
\hline Acrosiphonia flagellata & $-21.8 \pm 0.1$ & $6.0 \pm 0.1$ & $24.9 \pm 0.1$ & $0.34 \pm 0.00$ & & \\
\hline \multicolumn{7}{|c|}{ Phylum HETEROKONTOPHYTA } \\
\hline \multicolumn{7}{|l|}{ Class Phaeophyceae } \\
\hline Chorda tomentosa & $-17.6 \pm 0.1$ & $6.1 \pm 0.1$ & $27.3 \pm 0.1$ & $0.35 \pm 0.00$ & & \\
\hline Fucus distychus & $-17.2 \pm 1.2$ & $3.1 \pm 0.2$ & $40.6 \pm 13.1$ & $0.37 \pm 0.02$ & & \\
\hline Laminaria spp. & $-18.7 \pm 0.6$ & $4.6 \pm 1.0$ & $28.9 \pm 3.4$ & $0.33 \pm 0.01$ & & \\
\hline \multicolumn{7}{|l|}{ Phylum ANNELIDA } \\
\hline \multicolumn{7}{|l|}{ Class Polychaeta } \\
\hline Lumbrineris mixochaeta & $-20.1 \pm 0.1$ & $11.2 \pm 0.1$ & 3.5 & $0.34 \pm 0.01$ & $\mathrm{C}$ & 1 \\
\hline Travisia forbesii & $-17.5 \pm 0.0$ & $10.8 \pm 0.2$ & 3.4 & $0.12 \pm 0.00$ & DF & 2 \\
\hline Terebellides stroemii & $-20.2 \pm 0.0$ & $10.4 \pm 0.1$ & 3.3 & $0.37 \pm 0.00$ & SDF & 1 \\
\hline Scoloplos armiger & $-19.3 \pm 0.1$ & $9.1 \pm 0.0$ & 2.9 & $0.15 \pm 0.01$ & DF & 2 \\
\hline Phyllodoce groenlandica & $-19.6 \pm 0.0$ & $11.7 \pm 0.1$ & 3.7 & $0.40 \pm 0.00$ & $\mathrm{C}$ & 1 \\
\hline Chaetozone cf. setosa & $-20.8 \pm 0.1$ & $8.2 \pm 0.0$ & 2.6 & $0.27 \pm 0.00$ & SDF & 1 \\
\hline Ampharete spp. & $-19.8 \pm 0.0$ & $9.0 \pm 0.0$ & 2.9 & $0.34 \pm 0.00$ & SDF & 2 \\
\hline Aglaophamus malmgreni & $-18.7 \pm 0.0$ & $11.2 \pm 0.1$ & 3.5 & $0.33 \pm 0.00$ & $\mathrm{C}$ & 1 \\
\hline Maldane sarsi & $-19.6 \pm 0.1$ & $11.3 \pm 0.0$ & 3.6 & $0.29 \pm 0.00$ & DF & 1 \\
\hline Chone paucibranchiata & $-21.0 \pm 0.0$ & $7.1 \pm 0.1$ & 2.3 & $0.22 \pm 0.01$ & $\mathrm{~F}$ & 1 \\
\hline \multicolumn{7}{|l|}{ Phylum ARTHROPODA } \\
\hline \multicolumn{7}{|l|}{ Class Crustacea } \\
\hline Anonyx nugax & $-20.4 \pm 0.1$ & $12.1 \pm 0.1$ & 3.8 & $0.26 \pm 0.01$ & $\mathrm{C}$ & 1 \\
\hline Balanus balanus & $-19.8 \pm 0.1$ & $5.9 \pm 0.0$ & 2.0 & $0.30 \pm 0.00$ & $\mathrm{~F}$ & 1 \\
\hline Pagurus pubescens & $-20.6 \pm 0.0$ & $9.0 \pm 0.1$ & 2.9 & $0.27 \pm 0.00$ & $\mathrm{C}$ & 1 \\
\hline Lebbeus polaris & $-19.8 \pm 0.1$ & $8.9 \pm 0.0$ & 2.8 & $0.32 \pm 0.01$ & SC & 3 \\
\hline Sclerocrangon boreas & $-18.8 \pm 0.1$ & $10.9 \pm 0.2$ & 3.4 & $0.23 \pm 0.04$ & $\mathrm{C}$ & 3 \\
\hline Paroediceros lynceus & $-19.5 \pm 0.1$ & $10.3 \pm 0.1$ & 3.3 & $0.32 \pm 0.01$ & $\mathrm{SD}$ & 4 \\
\hline Sabinea septemcarinata & $-18.2 \pm 0.2$ & $10.0 \pm 0.1$ & 3.2 & $0.31 \pm 0.01$ & C & 3 \\
\hline Eualus gaimardii & $-19.5 \pm 0.1$ & $9.1 \pm 0.0$ & 2.9 & $0.35 \pm 0.01$ & $\mathrm{C}$ & 3 \\
\hline Spirontocaris spinus & $-19.9 \pm 0.1$ & $9.2 \pm 0.1$ & 2.9 & $0.38 \pm 0.01$ & $\mathrm{C}$ & 3 \\
\hline Thysanoessa inermis & $-21.6 \pm 0.0$ & $8.8 \pm 0.2$ & 2.8 & $0.37 \pm 0.01$ & $\mathrm{H}$ & 3 \\
\hline Pagurus pubescens, zoea & $-22.3 \pm 0.0$ & $7.4 \pm 0.0$ & $2.4 * * *$ & $0.35 \pm 0.01$ & $\mathrm{H}$ & 3 \\
\hline Calanus finmarchicus & $-25.0 \pm 0.0$ & $8.0 \pm 0.1$ & $2.6 * * *$ & $0.24 \pm 0.00$ & $\mathrm{H}$ & 3 \\
\hline Pandalus borealis & $-20.9 \pm 0.0$ & $7.3 \pm 0.1$ & 2.4 & $0.34 \pm 0.00$ & $\mathrm{H}$ & 3 \\
\hline \multicolumn{7}{|l|}{ Phylum BRYOZOA } \\
\hline \multicolumn{7}{|l|}{ Class Gymnolaemata } \\
\hline Escharella dijmphnae & $-20.3 \pm 2.6$ & $8.8 \pm 0.1$ & 2.9 & nd & $\mathrm{F}$ & 5 \\
\hline \multicolumn{7}{|l|}{ Phylum CEPHALORYNHA } \\
\hline \multicolumn{7}{|l|}{ Class Priapulida } \\
\hline Halicryptus spinulosus & $-18.8 \pm 0.5$ & $9.5 \pm 0.2$ & 3.0 & $0.13 \pm 0.04$ & $\mathrm{C}$ & 2 \\
\hline Priapulus caudatus & $-19.9 \pm 0.0$ & $10.3 \pm 0.1$ & 3.3 & $0.27 \pm 0.00$ & $\mathrm{C}$ & 2 \\
\hline
\end{tabular}


Table 1 continued

\begin{tabular}{|c|c|c|c|c|c|c|}
\hline Component/taxonomic group & $\delta^{13} \mathrm{C}$ & $\delta^{15} \mathrm{~N}$ & $\mathrm{C} / \mathrm{N}, \mathrm{RTL}$ & C content & Feeding mode & Reference \\
\hline \multicolumn{7}{|l|}{ Phylum CHAETOGNATHA } \\
\hline \multicolumn{7}{|l|}{ Class Sagittoidea } \\
\hline$\underline{\text { Sagitta }} \underline{\text { spp. }}$ & $-22.9 \pm 0.0$ & $11.5 \pm 0.3$ & $3.6 * * *$ & $0.35 \pm 0.02$ & $\mathrm{C}$ & 6 \\
\hline \multicolumn{7}{|l|}{ Phylum CHORDATA } \\
\hline \multicolumn{7}{|l|}{ Class Ascidiacea } \\
\hline Ascidia prunum & $-19.8 \pm 0.3$ & $14.4 \pm 0.0$ & 4.5 & $0.19 \pm 0.02$ & $\mathrm{~F}$ & 7 \\
\hline \multicolumn{7}{|l|}{ Class Pisces } \\
\hline Lumpenus lampretaeformis & $-21.0 \pm 0.0$ & $9.7 \pm 0.1$ & 3.1 & $0.14 \pm 0.00$ & $\mathrm{C}$ & 2 \\
\hline Triglops murrayi & $-20.9 \pm 0.1$ & $8.5 \pm 0.1$ & 2.7 & $0.13 \pm 0.00$ & $\mathrm{C}$ & 2 \\
\hline Mallotus villosus & $-21.6 \pm 0.0$ & $8.5 \pm 0.1$ & 2.7 & $0.12 \pm 0.00$ & $\mathrm{C}$ & 3 \\
\hline Agonus decagonus & $-20.9 \pm 0.1$ & $8.6 \pm 0.9$ & 2.8 & $0.03 \pm 0.01$ & $\mathrm{C}$ & 3 \\
\hline \multicolumn{7}{|l|}{ Phylum CNIDARIA } \\
\hline \multicolumn{7}{|l|}{ Class Anthozoa } \\
\hline$\underline{\text { Sarsia tubulosa }}$ & $-23.8 \pm 0.0$ & $7.0 \pm 0.1$ & $2.0 * * *$ & $0.20 \pm 0.00$ & $\mathrm{C}$ & 8 \\
\hline Halitholus cirratus & $-24.4 \pm 0.0$ & $7.7 \pm 0.1$ & $2.3 * * *$ & $0.22 \pm 0.00$ & $\mathrm{C}$ & 9 \\
\hline \multicolumn{7}{|l|}{ Phylum ECHINODERMATA } \\
\hline \multicolumn{7}{|l|}{ Class Ophiuroidea } \\
\hline Amphiura sundevalli & $-18.3 \pm 0.4$ & $10.7 \pm 0.1$ & 3.4 & $0.07 \pm 0.01$ & SDF & 1 \\
\hline Ophiura sarsi & $-18.1 \pm 4.1$ & $8.4 \pm 0.4$ & 2.7 & $0.04 \pm 0.01$ & $\mathrm{C} / \mathrm{SDF}$ & 2 \\
\hline \multicolumn{7}{|l|}{ Phylum MOLLUSCA } \\
\hline \multicolumn{7}{|l|}{ Class Bivalvia } \\
\hline Astarte borealis & $-19.3 \pm 0.0$ & $6.2 \pm 0.0$ & 2.1 & $0.38 \pm 0.00$ & $\mathrm{~F}$ & 1 \\
\hline Astarte elliptica & $-20.2 \pm 0.4$ & $6.5 \pm 0.3$ & 2.2 & $0.36 \pm 0.08$ & $\mathrm{~F}$ & 10 \\
\hline Ciliatocardium ciliatum & $-19.7 \pm 0.0$ & $6.0 \pm 0.1$ & 2.0 & $0.38 \pm 0.00$ & $\mathrm{~F}$ & 1 \\
\hline Hiatella arctica & $-19.8 \pm 0.1$ & $6.9 \pm 0.1$ & 2.2 & $0.33 \pm 0.01$ & $\mathrm{~F}$ & 2 \\
\hline Mya truncata & $-19.7 \pm 0.4$ & $6.0 \pm 0.4$ & 2.0 & $0.38 \pm 0.01$ & $\mathrm{~F}$ & 3 \\
\hline Yoldia hyperborea & $-19.3 \pm 0.0$ & $6.5 \pm 0.2$ & 2.3 & $0.41 \pm 0.00$ & $\mathrm{~F}$ & 1 \\
\hline Macoma calcarea & $-21.7 \pm 0.2 * *$ & $6.6 \pm 0.3$ & 1.8 & $0.03 \pm 0.00$ & $\mathrm{~F}$ & 1 \\
\hline Portlandia arctica & $-20.3 \pm 0.0$ & $7.0 \pm 0.1$ & 2.2 & $0.42 \pm 0.00$ & $\mathrm{~F}$ & 1 \\
\hline \multicolumn{7}{|l|}{ Class Gastropoda } \\
\hline Cryptonatica affinis & $-18.5 \pm 0.1$ & $8.9 \pm 0.1$ & 2.8 & $0.39 \pm 0.00$ & $\mathrm{C} / \mathrm{SC}$ & 11 \\
\hline Euspira pallida & $-19.0 \pm 0.0$ & $10.0 \pm 0.1$ & 3.2 & $0.36 \pm 0.00$ & $\mathrm{C} / \mathrm{SC}$ & 9 \\
\hline$\underline{\text { Clione limacina }}$ & $-23.2 \pm 0.0$ & $8.4 \pm 0.1$ & $2.7 * * *$ & $0.22 \pm 0.00$ & $\mathrm{C}$ & 2 \\
\hline \multicolumn{7}{|l|}{ Phylum SIPUNCULA } \\
\hline \multicolumn{7}{|l|}{ Class Sipunculida } \\
\hline Golfingia vulgaris & $-19.6 \pm 0.0$ & $8.3 \pm 0.1$ & 2.7 & $0.25 \pm 0.00$ & DF & 12 \\
\hline
\end{tabular}

Data (except SPOM) are presented as mean \pm SD (number of replicates/pools $n=3$ ). Feeding mode for faunal taxa was assigned based on the references cited

$* n=1, * * n=2, * * *$ calculated using the nitrogen isotope baseline for the pelagic fraction $(7.4 \%$ ). Pelagic taxa are underlined. Feeding mode: $C$ carnivore, $D F$ detritus-feeder, $S D F$ surface detritus-feeder, $F$ filter-feeder, $S C$ scavenger, $H$ herbivore, $S P O M$ suspended particulate organic matter, SOM sediment detritus

1 Kędra et al. (2010), ${ }^{2}$ Klekowski and Węsławski (1990), ${ }^{3}$ Węsławski et al. (2006), ${ }^{4}$ Węsławski et al. (2010b), ${ }^{5}$ Ryland (1970), ${ }^{6}$ Cosper and Reeve (1975), ${ }^{7}$ Eleftheriou and Basford (1989), ${ }^{8}$ Daan (1986), ${ }^{\mathbf{9}}$ Larson and Harbison (1989), ${ }^{10} \mathrm{http}: / / \mathrm{www} . \mathrm{marinespecies.org},{ }^{11} \mathrm{Wildish}$ and Peer (1981), ${ }^{12}$ Gibbs (1977)

(C. limacina), chaetognath (Sagitta spp.), and two pelagic cnidarians ( $S$. tubulosa and $H$. cirratus) had markedly impoverished carbon isotope ratios (mean $\delta^{13} \mathrm{C}-23.6 \pm$ $1.0 \%, n=18$ ) compared with the $\delta^{13} \mathrm{C}$ values of other fauna (mean $\delta^{13} \mathrm{C}-19.9 \pm 1.1 \%$, $n=125$; MannWhitney $U$ test: $Z=-3.68, p<0.001$ ) (Fig. 3). This pelagic fauna collected from 3 to $20 \mathrm{~m}$ above the sea floor was therefore analyzed separately from benthic animals. 
Food web structure

\section{Benthic component}

When a trophic enrichment factor of $1.0 \%$ for $\delta^{13} \mathrm{C}$ and $3.4 \%$ for $\delta^{15} \mathrm{~N}$ was applied to trophic relations, the carbon and nitrogen data of primary consumers indicated sediment detrital organic matter, SOM, as the principal carbon source for the macrobenthic community. A single trophic pathway is thus based almost exclusively on bottom sediments (Fig. 3), the topmost layer of which can be resuspended by the bottom currents to provide food for benthic filter-feeders. The stable carbon and nitrogen isotope composition of macrofauna was inconsistent with the isotopic signature of SPOM and the analyzed benthic macroalgae (Fig. 3), indicating that these potential carbon sources are not directly utilized by benthic animals. Macroalgae may contribute to the organic matter pool assimilable by consumers, only in the form of detrital material transported from coastal areas. The calculated nitrogen isotope baseline for the benthic food web was $6.0 \%$ and the FCL 4.5 .

Cluster analysis of $\delta^{13} \mathrm{C}$ and $\delta^{15} \mathrm{~N}$ in 42 benthic faunal taxa separated them into four groups (Figs. 3, 4). The choice of cutoff points that define the separate clusters is somewhat arbitrary, but comparison between the cluster results and the available biological and ecological information provided a useful basis for describing the different feeding patterns. Filter-feeders, i.e., suspension-, deposit-, or facultative suspension/deposit-feeders (Group 1), including all bivalves (eight species), two crustaceans and a polychaete, had the lowest $\delta^{15} \mathrm{~N}(5.9 \pm 0.0 \%$ $7.3 \pm 0.1 \%$ ) and relative trophic level (RTL; from 1.8 to 2.4). Intermediate nitrogen stable isotope values of between $8.2 \pm 0.0 \%$ and $9.2 \pm 0.1 \%$ characterized organisms with a mixed feeding mode (Group 2, RTL 2.6-2.9): scavengers/deposit-feeders/carnivores including crustaceans (five species), polychaetes (three species), fish (three species), the ophiuroid Ophiura sarsi, the sipunculid Golfingia vulgaris, and the colonial sessile bryozoan Escharella dijmphnae. A markedly higher trophic level (RTL 3.0-3.8) of $\delta^{15} \mathrm{~N}$ ranging from $9.5 \pm 0.2 \%$ to $12.1 \pm 0.1 \%$ was recorded in a large cluster of benthic animals (Group 3; 14 taxa), encompassing sedentary polychaetes (six species), priapulids (two species), the gastropod Euspira pallida, actively moving crustaceans (four species) and one ophiuroid Amphiura sundevallis. Finally, the top predators (Group 4) were represented by a single ascidian species $A$. prunum, which showed the highest $\delta^{15} \mathrm{~N}(14.4 \pm 0.0 \%)$ and RTL (4.5), indicative of its exclusive carnivory.

The number of species in subsequent trophic levels decreased with trophic position, shaping the hierarchical structure of the trophic pyramid. Twenty-five benthic species were assigned to the second trophic level (RTL 1.8-3.0), 16 species to the third trophic level (RTL $3.0-4.0$ ), and the benthic top predators group included only one species $($ RTL $>4.0)$ (Table 1$)$. Primary consumers acquired the most biomass (62\% of the total macrobenthic biomass), and the contribution of the secondary consumers was $38 \%$.

\section{Pelagic component}

The nitrogen isotope baseline for the pelagic fraction was $7.0 \%$, and two trophic levels could be distinguished. The primary consumers (RTL 2.0-2.4) were comprised of typically planktonic cnidarians (S. tubulosa and $H$. cirratus), crustaceans (P. pubescens, zoea and C. finmarchicus), and a gastropod (C. limacina) (Fig. 3). The only carnivorous animal was the neritic chaetognath Sagitta spp. (RTL 3.6). The carbon and nitrogen isotope ratios of pelagic primary consumers were inconsistent with the isotopic signature of any analyzed SPOM, assuming stepwise trophic enrichment of 1.0 and $3.4 \%$ for $\delta^{13} \mathrm{C}$ and $\delta^{15} \mathrm{~N}$, respectively. Several crustaceans, however, probably undergo daily vertical migration (e.g., C. finmarchicus), so that they may feed on surface water SPOM $_{\text {surf }}$ and $\mathrm{SPOM}_{\text {bot }}$ in the overlying bottom water at different times in the daily cycle.

\section{Discussion}

Carbon sources for the food web

The carbon and nitrogen isotopic composition and the $\mathrm{C} / \mathrm{N}$ ratio of SPOM (Table 1) in Hornsund generally fell within the intermediate range typical for sub-Arctic and Arctic waters, i.e., from -21.1 to $-27.7 \%$ for $\delta^{13} \mathrm{C}$, from 4.2 to $8.2 \%$ for $\delta^{15} \mathrm{~N}$, and from 5.5 to 8.7 for $\mathrm{C} / \mathrm{N}$ (compiled data from Hobson and Welch 1992; Hobson et al. 1995, 2002; Cooper et al. 2002; Tamelander et al. 2006; Iken et al. 2010). Direct comparison with the isotopic composition of SPOM sampled in Kongsfjorden, located approximately $220 \mathrm{~km}$ to the north $\left(78^{\circ} \mathrm{N}\right)$, revealed impoverished $\delta^{13} \mathrm{C}$ and enriched $\delta^{15} \mathrm{~N}$ of sestonic organic matter in Hornsund (Renaud et al. 2011; Kędra et al. 2012). Hornsund and Kongsfjorden are both glacial fjords on the west coast of Spitsbergen that are under the influence of the relatively warm Atlantic waters, although the former is more affected by the cold Sørkapp Current carrying Arctic waters (Kędra et al. 2010). The more negative $\delta^{13} \mathrm{C}$ values in Hornsund can thus be attributed to an increase in the dissolved $\mathrm{CO}_{2}$ pool due to lower temperatures, which results in greater isotopic fractionation during carbon assimilation (Rau et al. 
1992). In addition, higher primary production rates and total phytoplankton biomass in summer have been reported from Hornsund, indicating relatively good nutritional conditions and preferable utilization of heavier ${ }^{15} \mathrm{~N}$ from the water column in photosynthesis. In contrast, the low availability of nutrients in Kongsfjorden accounts for reduced phytoplankton assemblages (Piwosz et al. 2009) and a shift in the nitrogen isotope signature of SPOM toward lower (depleted) values. Under nutrient limitation, the contribution of light atmospheric nitrogen to primary production increases and slight isotopic fractionation occurs during the assimilation of dissolved inorganic nitrogen by phytoplankton (Wada and Hattori 1991). Another possible reason for the lower $\delta^{15} \mathrm{~N}$ values in Kongsfjorden relative to those in Hornsund could be the recycling of ammonium and the utilization by bacteria of isotopically light $\mathrm{NH}_{4}{ }^{+}$, which leads to impoverishment of ${ }^{15} \mathrm{~N}$, particularly in seston that is not dominated by photosynthetically active cells (Checkley $\mathrm{Jr}$ and Entzeroth 1985).

Physico-biochemical mechanisms can explain the observed differences in stable carbon and nitrogen isotope ratios and $\mathrm{C} / \mathrm{N}$ of SPOM between surface and overlying bottom waters in Hornsund (Table 1). The $\delta^{13} \mathrm{C}$ and $\delta^{15} \mathrm{~N}$ were lower, and the $\mathrm{C} / \mathrm{N}$ ratio was greater for $\mathrm{SPOM}_{\mathrm{bot}}$ than for $\mathrm{SPOM}_{\text {surf }}$, implying resuspension of isotopically heavier material from the bottom into the water column by turbulent water movements (Węsławski et al. 1991) and/or transformation of sestonic organic matter in the water column. During sedimentation of ${ }^{15} \mathrm{~N}$-rich phytoplanktonic cells, biogenic mineralization of settled particles through the diagenesis of organic matter (Cifuentes et al. 1996) increases the $\mathrm{C} / \mathrm{N}$ ratio in suspension over the sea floor (Wu et al. 2003). The higher $\mathrm{C} / \mathrm{N}$ ratio in Hornsund, however, did not correspond to a more positive $\delta^{15} \mathrm{~N}$ in the overlying bottom water, indicating the involvement of other processes in the nitrogen transformation of SPOM. The source of isotopically light nitrogen in $\mathrm{SPOM}_{\text {bot }}$ is likely to be inorganic nitrogen that is assimilated through microbial activity (Coffin and Cifuentes 1999). Incorporation of isotopically light dissolved inorganic nitrogen into bacteria resulting in decreased $\delta^{15} \mathrm{~N}$ in SPOM was also observed under pack ice in the north-central Bering Sea during winter (Lovvorn et al. 2005). This conclusion is supported by ammonium enrichment in the deeper waters and sediments due to the remineralization of settled particles and high bacterial activity (Arnosti and Jørgensen 2003).

Microbial activity at the water-sediment interface also accounts for the increased $\mathrm{C} / \mathrm{N}$ ratio (up to 10.2) in bottom sediments due to the removal of nitrogen or the breakdown of organic material (Cifuentes et al. 1988). In addition, the preferential utilization of ${ }^{15} \mathrm{~N}$-poor ammonium by bacteria at permanently low temperatures induces a decrease in SOM $\delta^{15} \mathrm{~N}$ (down to $4.2 \%$ ), a phenomenon that is also observed in deep sediments of the eastern Fram Strait (Bergmann et al. 2009). Deposited phytoplankton may be slightly ${ }^{13} \mathrm{C}$-enriched after sedimentation, through recycling across the microbial loop (Hobson et al. 1995). The relatively high $\delta^{13} \mathrm{C}$ levels in SOM may also result from the influence of $\delta^{13} \mathrm{C}$-enriched macroalgae (Table 1), which densely inhabit the tidal zone near the sampling site (Węsławski et al. 2010a). It appears that the enriched ${ }^{13} \mathrm{C}$ and impoverished ${ }^{15} \mathrm{~N}$ isotopic signal of SOM reflects the mix of impoverished SPOM with heavier refractory macroalgae from the coastal zone that accumulate on the sea floor and undergo bacteria-mediated transformation (Fig. 2).

Structure of the food web

\section{Benthic community}

The $\delta^{13} \mathrm{C}$ of potential organic matter sources was markedly different, which may permit identification of the principal carbon source for the benthic food web. Benthic primary consumers were more depleted in $\delta^{13} \mathrm{C}$ (by at least $0.6 \%$ ) than coastal macroalgae (except the green alga A. flagellata) and had much more enriched carbon isotope ratios (by at least $2.1 \%$ ) that those of $\mathrm{SPOM}_{\text {bot }}$. Due to such differences in $\delta^{13} \mathrm{C}$, neither of these potential food sources can be unequivocally identified as the main food of the macrozoobenthos in the outer basin of Hornsund, assuming trophic enrichment between the consumer and its diet of 1.0 and $3.4 \%$ for $\delta^{13} \mathrm{C}$ and $\delta^{15} \mathrm{~N}$, respectively. This may be due to the mixed diet of these organisms, consisting of variable amounts of SOM and benthic algae. It is more likely, however, that benthic fauna inhabiting the $100-\mathrm{m}-$ deep soft bottom rely primarily on sediment detrital organic matter, SOM, as was also observed for sedentary benthic fauna in the southeastern Chukchi Sea (Feder et al. 2011). This organic matter is supplied by suspended particulate matter and horizontal transport of macroalgae from the nearby euphotic coastal zone. Through resuspension by bottom currents, deposited organic particles also contribute to the diet of suspension-feeding bivalves, polychaetes, crustaceans, cnidarians, and a bryozoan. This finding contrasts with those relating to other nearshore (e.g., Tamelander et al. 2006; Renaud et al. 2011; Kędra et al. 2012) and open sea (Iken et al. 2010) Arctic benthic food webs, which are almost exclusively based on SPOM or iceSPOM, highlighting the different hydrological and sedimentological conditions in Hornsund.

The trophic web structure determined from the isotopic evidence was consistent with known feeding habits and revealed other less well-known trophic relationships in the 
Fig. 3 Average stable carbon and stable nitrogen isotope values in pelagic and benthic components of the Hornsund food web. Groups of organisms were classified using hierarchical cluster analysis of Bray-Curtis dissimilarities with Ward's minimum variance method of double-roottransformed $\delta^{13} \mathrm{C}$ and $\delta^{15} \mathrm{~N}$ values. Each symbol represents a different species. SPOM-GF/D and SPOM-GF/F denote 180-2.7 and 0.7-2.7 $\mu \mathrm{m}$ suspended particulate organic matter size fractions, respectively, and SOM refers to sediment detritus

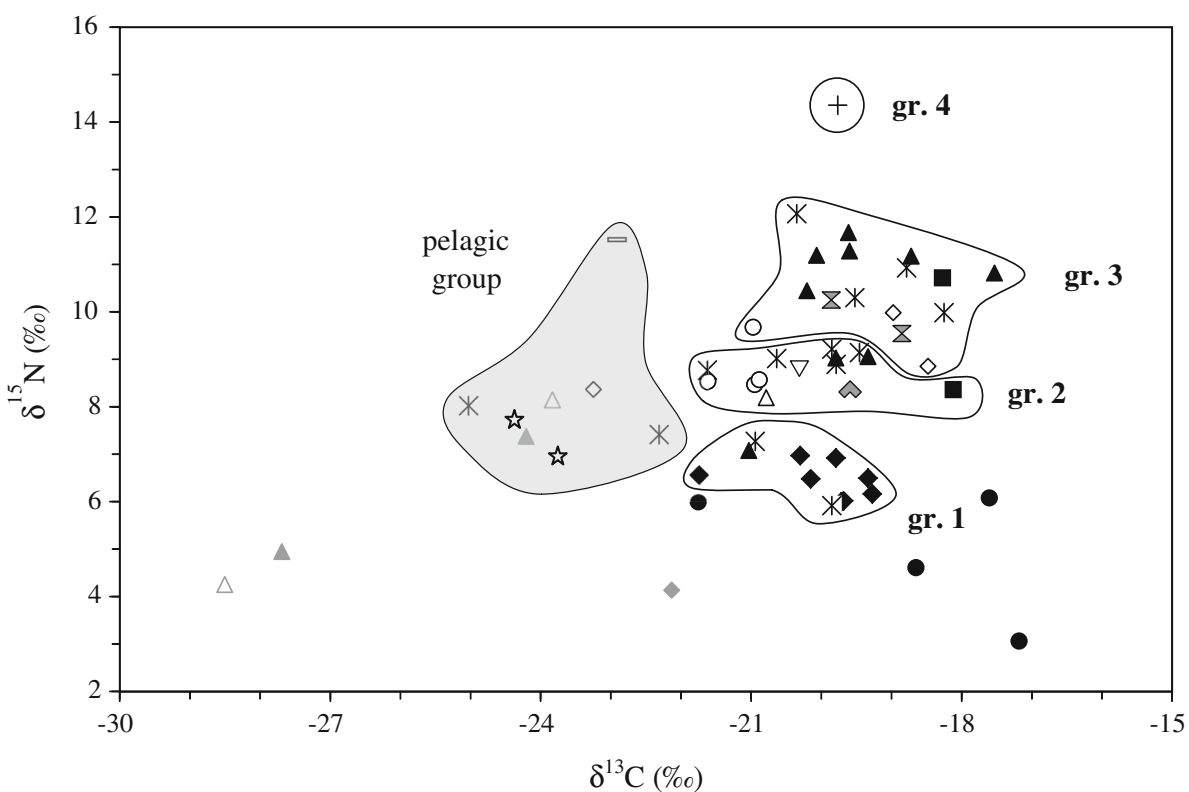

\begin{tabular}{|llllll|}
\hline+ Ascidiacea & $\diamond$ Bivalvia & $\nabla$ Bryozoa & $=$ Chaetognatha & $\star$ Cnidaria & $*$ Crustacea \\
Echinodermata & $\diamond$ Gastropoda & o Pisces & $\Delta$ Polychaeta & $\nabla$ Priapulida & $\diamond$ Sipunculida \\
$\Delta$ SPOM-GF/D & $\Delta$ SPOM-GF/F & $\diamond$ SOM $<63 \mu \mathrm{m}$ & $\bullet$ macroalgae & & \\
\hline
\end{tabular}

fjord. The majority of primary consumers (Groups 1 and 2) were filter-feeders (ten taxa) and deposit-feeders (five taxa). The wide range of $\delta^{15} \mathrm{~N}$ within the second trophic level (5.9-9.2\%o), however, indicates a broad diet spectrum and feeding that is not based strictly on sediment detritus (SOM). There is also the possibility that the observed differences in $\delta^{15} \mathrm{~N}$ within primary consumers could reflect the physiological condition of the animals (e.g., starvation), their growth efficiency, and the nitrogen content of the available food (specifically the protein and amino acid concentrations) (Vanderklift and Ponsard 2003). The isotopic signatures of all bivalve species, filter-feeding crustaceans (B. balanus and zooplanktonic Pandalus borealis), and the single polychaete (Chone paucibranchiata) were inconsistent with the $\delta^{13} \mathrm{C}$ and $\delta^{15} \mathrm{~N}$ of any one of the organic matter sources analyzed. Inflow of suspended organic particles from other areas with bottom currents (e.g., from the more productive euphotic zone or from the Atlantic Ocean) may provide food sources for benthic filterfeeders. Warmer and more saline water masses of the West Spitsbergen Current easily penetrate into Hornsund at a depth of 70-100 m (Swerpel 1985), bringing suspended particles of Atlantic origin to benthic communities. The trophic level of animals in Group 2 (RTL 2.6-2.9) revealed a mixed feeding mode of selective detritivory, scavenging, and carnivory, suggesting generalistic feeding by these animals (Table 1). It is noteworthy that Group 2 also contained a typically filter-feeding bryozoan E. dijmphnae, which showed considerable ${ }^{15} \mathrm{~N}$-enrichment $(8.9 \%$ ) and an
RTL as high as 2.9. The higher stable nitrogen isotope ratio of E. dijmphnae compared with obligate filter-feeders (e.g., bivalves), supports the notion that this colonial animal also takes up smaller heterotrophic organisms such as microand nanoplanktonic protozoans and metazoans of $<50 \mu \mathrm{m}$ in size (Winston 1978).

Group 3 of secondary consumers was comprised of different species with a prevalent carnivorous feeding mode (RTL 3.0-3.8). However, detrital organic matter presumably originating from the breakdown of benthic fauna also appears to contribute to their dietary input. For example, the stable carbon and nitrogen isotope composition of two deposit-feeders, $T$. forbesii and Maldane sarsi, revealed that these polychaetes feed preferentially on highly reworked detritus of faunal origin (Kędra et al. 2012) in Hornsund. The highest $\delta^{15} \mathrm{~N}$ of the free-living lysianassoid amphipod Anonyx nugax indicated that carnivorous feeding behavior is dominant in this typical necrophagous amphipod, as was previously suggested for the same species inhabiting Kongsfjorden (Legeżyńska et al. 2012). The exceptionally depleted $\delta^{13} \mathrm{C}$ values observed in the snakeblenny Lumpenus lampretaeformis can be attributed to the dietary input of plant material in the form of fresh or decaying thallus. Although this carnivorous fish has previously been reported to feed on small crustaceans, molluscs, brittle stars, and worms (Wheeler 1992), the isotopic signature of both carbon and nitrogen indicate an important contribution of macroalgae (e.g., A. flagellata) in its diet. 
Fig. 4 Hierarchical clustering of Bray-Curtis dissimilarities (Ward's minimum variance method) of double-root transformed $\delta^{13} \mathrm{C}$ and $\delta^{15} \mathrm{~N}$ for 42 benthic species sampled in Hornsund. Gray bars indicate the estimated relative trophic level (RTL)

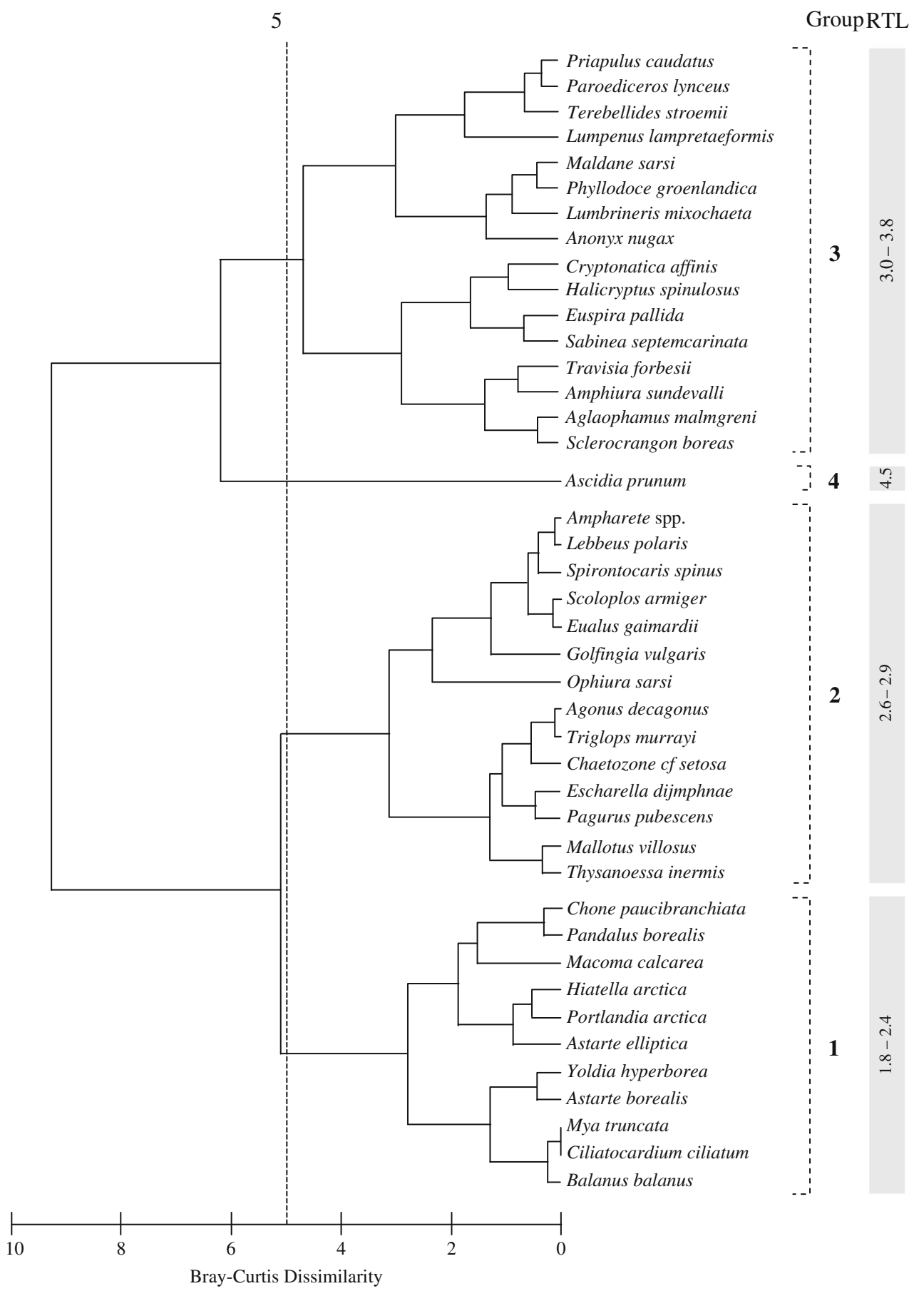

The trophic position (RTL 4.5) of the sessile filterfeeding ascidian $A$. prunum revealed its exclusive carnivorous feeding habit (Figs. 3,4). The top predatory level of this tunicate is surprising since its filter is capable of retaining a wide range of seston types, typically between 3 and $70 \mu \mathrm{m}$ in size, that include mainly bacteria, diatoms and other phytoplankton, and non-living detritus. The increased $\delta^{15} \mathrm{~N}$ value suggests that $A$. prunum selectively consumes microzooplankton such as invertebrate larvae (including conspecifics in some cases; Bingham and Walters 1989), which represent a greater trophic level distance (1.0-2.0) from the phytoplankton.

Principal attributes of the benthic food web

The dual stable isotope ratio technique demonstrated its utility in tracing the flow of organic matter in benthic communities in this cold Arctic fjord of southwestern 
Spitsbergen. The analyses of the $\delta^{13} \mathrm{C}$ and $\delta^{15} \mathrm{~N}$ in abiotic compartments and macroorganisms revealed a food chain of average length (FCL 4.5) in Hornsund, i.e., similar to other coastal Arctic ecosystems such as the Chukchi Sea (Iken et al. 2010), Kongsfjorden (Renaud et al. 2011) and the Alaskan Beaufort Sea (Dunton et al. 2012). Hastings and Conrad (1979) argued that the main factor determining the number of trophic levels is the quality of organic matter sources (e.g., the C/nutrient ratio) and not their quantity, as is often highlighted in discussions of food web length. In the outer part of Hornsund, the average food chain length can thus reflect the availability of large and energy-rich prey items for predators, as suggested by Węsławski et al. (2006). The benthic food web in this fjord has a typical organization, with a decreasing number of species in subsequent trophic levels (Belgrano et al. 2005). Primary consumers feeding on a mixture of plant matter, bacteria, and protists acquired the most biomass (62\% of the total macrobenthic biomass) with a steep decrease in biomass to the secondary consumers ( $38 \%)$, which reflects the conventional trophic structure. This pattern depicts diminishing amounts of energy available to support each subsequent trophic level.

\section{Planktonic component}

In the water layer 3-20 m above the sea floor, several typically planktonic species were found that formed a separate isotopic group. Primary consumers (cnidarians, crustaceans, and a gastropod) exhibited isotopic signatures that were inconsistent with those of any of the potential organic carbon sources analyzed. Therefore, the food for these planktonic species (including both phytoplankton and small zooplankton) might originate from other regions and is transported in sea currents to the outer part of the fjord. This would be in accordance with the findings that $\mathrm{SPOM}_{\text {bot }}$ analyzed at site A1 apparently makes only a minor contribution as a food source to the resident benthic filter-feeding consumers, and suspended particulate organic matter in the overlying bottom water is strongly affected by local hydrodynamics. Furthermore, the input of decaying SPOM with reduced $\delta^{13} \mathrm{C}$ as an alternative carbon source in the overlying bottom water cannot be excluded. Another plausible explanation is horizontal advection of planktonic animals to the entrance of Hornsund from the Atlantic shelf in the relatively warmer water masses of the West Spitsbergen Current (Swerpel 1985; Węsławski et al. 1991), where SPOM and pelagic consumers were found to be enriched in $\delta^{13} \mathrm{C}$. No data, however, are available on the carbon and nitrogen isotopic composition of pelagic fauna from these neighboring open-ocean waters. It is also possible that the diets of zooplankton included a substantial fraction of pelagic bacteria whose biomass often increases relative to that of phytoplankton in Arctic waters during the summer (Garneau et al. 2008). The only exclusively carnivorous taxon was the holoplanktonic Sagitta spp. (Chaetognatha), which is an active foraging predator that feeds almost exclusively on planktonic crustaceans and fish larvae.

\section{Conclusions}

The combined data on $\delta^{13} \mathrm{C}$ and $\delta^{15} \mathrm{~N}$ revealed sediment detrital organic matter (SOM) to be the principal food source for the macrobenthic community in the outer part of Hornsund. Isotopic ratios of SOM presumably result from the mixing of mineralized SPOM with heavier refractory macroalgae from the nearby coastal zone that accumulate on the sea floor and undergo bacteria-mediated transformation. Through resuspension by bottom currents, organic particles deposited on a muddy sea floor also contribute to the diet of typical suspension-feeding benthic animals. The inconsistency of the isotopic signatures of benthic and epibenthic primary consumers with those of SPOM and macroalgae indicates that neither of these sources of organic matter constitute the major dietary input of the resident benthic fauna. This finding contrasts with those of studies examining many other Arctic coastal benthic food webs that are almost exclusively based on SPOM or iceSPOM, highlighting the different hydrological and sedimentological conditions in this fjord. Benthic species were significantly enriched in ${ }^{13} \mathrm{C}$ compared to planktonic species, which permits the definition of benthic versus pelagic feeding preferences. The benthic food web demonstrates conventional trophic organization, with a decreasing number of species in subsequent trophic levels. The benthic community in Hornsund has an average food chain length (FCL 4.5 trophic levels), suggesting good availability of high-quality food in this system.

Acknowledgments This study was supported by the EU Network of Excellence "Marine Biodiversity and Ecosystem Functioning" (MarBEF; GOCE-CT-2003-505446) and by grant no N N304 162237 from the Ministry of Science and Higher Education, Poland. Joanna Legeżyńska, Emilia Trudnowska, Rafał Boehnke and Edyta Malec from the Institute of Oceanology, Polish Academy of Sciences, Sopot, Poland are acknowledged for their help during taxonomic identification of Arctic invertebrates. A.S. wishes to thank Gaele Guillou from Littoral, Environnement et Sociétés (LIENSs), Université de La Rochelle, La Rochelle, France, for his assistance during stable isotope analyses. Thanks are due to Dr John Gittins from the University of Southampton, Southampton, UK for his help in improving the English.

Open Access This article is distributed under the terms of the Creative Commons Attribution License which permits any use, distribution, and reproduction in any medium, provided the original author(s) and the source are credited. 


\section{References}

Aanes R, Sæther B-E, Smith FM, Cooper EJ, Wookey PA, Øritsland NA (2002) The Arctic oscillation predicts effects of climate change in two trophic levels in a high-arctic ecosystem. Ecol Lett 5:445-453

Arctic Climate Impact Assessment (ACIA) (2004) Impacts of a warming Arctic: Arctic climate impact assessment. Cambridge University Press, Cambridge, http://www.acia.uaf.edu

Arnosti C, Jørgensen BB (2003) High activity and low temperature optima of extracellular enzymes in Arctic sediments: implications for carbon cycling by heterotrophic microbial communities. Mar Ecol Prog Ser 249:15-24

Belgrano A, Scharler UM, Dunne J, Ulanowicz RE (2005) Aquatic food webs. An ecosystem approach. Oxford University Press, New York

Berge J, Johnsen G, Nilsen F, Gulliksen B, Slagstad D (2005) Ocean temperature oscillations enable reappearance of blue mussels Mytilus edulis in Svalbard after 1000 year absence. Mar Ecol Prog Ser 303:167-175

Bergmann M, Dannheim J, Bauerfeind E, Klages M (2009) Trophic relationships along a bathymetric gradient at the deep-sea observatory HAUSGARTEN. Deep Sea Res I 56:408-424

Bingham BL, Walters LJ (1989) Solitary ascidians as predators of invertebrate larvae: evidence from gut analyses and plankton samples. J Exp Mar Biol Ecol 131:147-159

Boutton TW (1991) Stable carbon isotope ratios of natural materials; I. Sample preparation and mass spectrometric analysis. In: Coleman DC, Fry B (eds) Carbon isotope techniques. Academic Press, San Diego, pp 155-171

Buchholz F, Buchholz C, Węsławski JM (2010) Ten years after: krill as indicator of changes in the macro-zooplankton communities of two Arctic fjords. Polar Biol 33:101-113

Checkley DM Jr, Entzeroth LC (1985) Elemental and isotopic fractionation of carbon and nitrogen by marine, planktonic copepods and implications to the marine nitrogen cycle. J Plankton Res 7:553-568

Cifuentes L, Sharp JH, Fogel ML (1988) Stable carbon and nitrogen isotope biogeochemistry in the Delaware estuary. Limnol Oceanogr 33:1102-1115

Cifuentes LA, Coffin RB, Solorzano L, Cardenas W, Espinoza J, Twilley RR (1996) Isotopic and elemental variations of carbon and nitrogen in a mangrove estuary. Estuar Coast Shelf Sci 43:781-800

Coffin RB, Cifuentes LA (1999) Stable isotope analysis of carbon cycling in the Perdido estuary, Florida. Estuaries 22:917-926

Cooper LW, Grebmeier JM, Larsen IL, Egorov VG, Theodorakis C, Kelly HP, Lovvorn JR (2002) Seasonal variation in water column processes and sedimentation of organic materials in the St. Lawrence Island polynya region, Bering Sea. Mar Ecol Prog Ser 226:13-26

Cosper TC, Reeve MR (1975) Digestive efficiency of the chaetognath Sagitta hispida conant. J Exp Mar Biol Ecol 17:33-38

Coyle KO, Konar B, Blanchard A, Highsmith RC, Carroll J, Carroll M, Denisenko SG, Sirenko BI (2007) Potential effects of temperature on the benthic infaunal community on the southeastern Bering Sea shelf: possible impacts of climate change. Deep Sea Res II 54:23-26

Daan R (1986) Food intake and growth of Sarsia tubulosa (SARS, 1835), with quantitative estimates of predation on copepod populations. Neth J Sea Res 20:67-74

Davenport SR, Bax NJ (2002) A trophic study of a marine ecosystem off southeaster Australia using stable isotopes of carbon and nitrogen. Can J Fish Aquat Sci 59:514-530

Duffy JE, Cardinale BJ, France KE, McIntyre PB, Thébault E, Loreau M (2007) The functional role of biodiversity in food webs: incorporating trophic complexity. Ecol Lett 10:522-538
Dunton KH, Schonberg SV, Cooper LW (2012) Food web structure of the Alaskan nearshore shelf and estuarine lagoons of the Beaufort Sea. Estuar Coast 35:416-435

Eleftheriou A, Basford DJ (1989) The macrobenthic infauna of the offshore northern North Sea. J Mar Biol Assoc UK 69:123-143

Feder HM, Iken K, Blanchard AL, Jewett SC, Schonberg S (2011) Benthic food web structure in the southeastern Chukchi Sea: an assessment using $\delta^{13} \mathrm{C}$ and $\& \delta 15 \mathrm{~N}$ analyses. Polar Biol 34:521-532

Garneau M, Roy S, Lovejoy C, Gratton Y, Vincent WF (2008) Seasonal dynamics of bacterial biomass and production in a coastal arctic ecosystem: Franklin Bay, western Canadian Arctic. J Geophys Res 113:C07S91

Gibbs PE (1977) On the status of Golfingia intermedia (Sipuncula). J Mar Biol Assoc UK 57:109-112

Grzelak K, Kotwicki L (2012) Meiofaunal distribution in Hornsund fjord, Spitsbergen. Polar Biol 35:269-280

Hastings A, Conrad M (1979) Length and evolutionary stability of food chains. Nature 140:799-814

Hobson KA, Welch HE (1992) Determination of trophic relationships within a high Arctic marine food web using $\delta^{13} \mathrm{C}$ and $\delta^{15} \mathrm{~N}$ analysis. Mar Ecol Prog Ser 84:9-18

Hobson KA, Ambrose WG Jr, Renaud PE (1995) Sources of primary production, benthic-pelagic coupling, and trophic relationships within the Northeast Water Polynya: insights from $\delta^{13} \mathrm{C}$ and $\delta^{15} \mathrm{~N}$ analysis. Mar Ecol Prog Ser 128:1-10

Hobson KA, Fisk AT, Karnovsky N, Holst M, Gagnon J-M, Fortier M (2002) A stable isotope $\left(\delta^{13} \mathrm{C}, \delta^{15} \mathrm{~N}\right)$ model for the North Water Polynya foodweb: implications for evaluating trophodynamics and the flow of energy and contaminants. Deep Sea Res II 49:5131-5150

Hop H, Falk-Petersen S, Svendsen H, Kwasniewski S, Pavlov V, Pavlova O, Søreide JE (2006) Physical and biological characteristics of the pelagic system across Fram Strait to Kongsfjorden. Prog Oceanogr 71:182-231

Horton TW, Blum JD, Xie Z, Hren M, Chamberlain CP (2009) Stable isotope food-web analysis and mercury biomagnification in polar bears (Ursus maritimus). Polar Res 28:443-454

Iken K, Bluhm B, Dunton K (2010) Benthic food-web structure under differing water mass properties in the southern Chukchi Sea. Deep Sea Res II 57:71-85

Intergovernmental Panel on Climate Change (IPCC) (2000) In: Nakicenovic N, Swart R (eds) Special report on emissions scenarios. Cambridge University Press, Cambridge, pp 239-292

Jacob U, Mintenbeck K, Brey T, Knust R, Beyer K (2005) Stable isotope food web studies: a case for standardized sample treatment. Mar Ecol Prog Ser 287:251-253

Jianhua G, Yaping W, Shaoming P, Rui Z, Jun L, Fenglong B (2008) Spatial distributions of organic carbon and nitrogen and their isotopic compositions in sediments of the Changjiang Estuary and its adjacent sea area. J Geogr Sci 18:46-58

Kędra M, Gromisz S, Jaskuła R, Legeżyńska J, Maciejewska B, Malec E, Opanowski A, Ostrowska K, Włodarska-Kowalczuk M, Węsławski JM (2010) Soft bottom macrofauna of an All Taxa Biodiversity Site: Hornsund (77 N, Svalbard). Pol Polar Res 31:309-326

Kędra M, Kuliński K, Walkusz W, Legeżyńska J (2012) The shallow benthic food web structure in the high Arctic does not follow seasonal changes in the surrounding environment. Estuar Coast Shelf Sci 114:183-191

Klekowski RZ, Węsławski JM (1990) Atlas of the marine fauna of southern Spitsbergen. Tom 1, Ossolineum, Wrocław

Larson RJ, Harbison GR (1989) Source and fate of lipids in polar gelatinous zooplankton. Arctic 42:339-346

Legeżyńska J, Kędra M, Walkusz W (2012) Trophic ecology of Arctic amphipods revealed by gut content, stable isotopes and lipid analysis. Hydrobiologia 684:189-214 
Lovvorn JR, Cooper LW, Brooks ML, De Ruyck CC, Bump JK, Grebmeier JM (2005) Organic matter pathways to zooplankton and benthos under pack ice in late winter and open water in late summer in the north-central Bering Sea. Mar Ecol Prog Ser 291:135-150

Olive PJW, Pinnegar JK, Polunin NVC, Richards G, Welch R (2003) Isotope trophic-step fractionation: a dynamic equilibrium model. J Anim Ecol 72:608-617

Piechura J, Beszczyjska-Moller A, Osijski R (2001) Volume, heat and salt transport by the West Spitsbergen current. Polar Res 20:233-240

Piwosz K, Walkusz W, Hapter R, Wieczorek P, Hop H, Wiktor J (2009) Comparison of productivity and phytoplankton in a warm (Kongsfjorden) and a cold (Hornsund) Spitsbergen fjord in midsummer 2002. Polar Biol 32:549-559

Polyakov IV, Beszczynska A, Carmack EC, Dmitrenko IA, Farbarch E, Frolov IE, Gerdes R, Hansen E, Holfort J, Ivanov VV, Johnson MA, Karcher M, Kauker F, Morison J, Orvik KA, Schauer U, Simmons HL, Skagseth $\varnothing$, Sokolov VT, Steele M, Timokhov LA, Walsh D, Walch JE (2005) One more step toward a warmer Arctic. Geophys Res Lett 32:1-4

Polyakov IV, Timokhov LA, Alexeev VA, Bacon S, Dimitrenko IA, Fortier L, Frolov IE, Gascard JC, Hansen E, Ivanov VV, Laxon S, Mauritzen C, Perovich D, Shimada K, Simmons HL, Sokolov VT, Steele M, Toole J (2010) Arctic Ocean warming contributes to reduced polar cap. J Phys Oceanogr 40:L2743-L2756

Post DM (2002) Using stable isotopes to estimate trophic positions: models, methods, and assumptions. Ecology 83:703-718

Rau GH, Takahashi T, Des Marais DJ, Repeta DJ, Martin JH (1992) The relationship between $\delta^{13} \mathrm{C}$ of organic matter and $\left[\mathrm{CO}_{2}(\mathrm{aq})\right]$ in ocean surface water: data from a JGOFS site in the northeast Atlantic Ocean and a model. Geochim Cosmochim Acta 56:1413-1419

Renaud PE, Caroll ML, Ambrose WG Jr (2008) Effects of global warming on Arctic sea-floor communities and its consequences for higher trophic levels. In: Duarte C (ed) Impacts of global warming on polar ecosystems. Fundacion BBVA, Bilbao, pp 139-177

Renaud PE, Tessmann M, Evenset A, Christensen GN (2011) Benthic food-web structure of an Arctic fjord (Kongsfjorden, Svalbard). Mar Biol Res 7:13-26

Ryland JS (1970) Bryozoans. Hutchinson University Library, London Smith CR, Grange LJ, Honig DL, Naudts L, Huber B, Guidi L, Domack E (2012) A large population of king crabs in Palmer Deep on the west Antarctic Peninsula shelf and potential invasive impacts. Proc R Soc B 279:1017-1026

Steele M, Ermold W, Zhang J (2008) Arctic Ocean surface warming trends over the past 100 years. Geophys Res Lett 35:L02614
Swerpel S (1985) The Hornsund fiord: water masses. Pol Polar Res 4:475-496

Tamelander T, Renaud PE, Hop H, Carroll ML, Ambrose WG Jr, Hobson KA (2006) Trophic relationships and pelagic-benthic coupling during summer in the Barents Sea Marginal Ice Zone revealed by stable carbon and nitrogen isotope measurements. Mar Ecol Prog Ser 310:33-46

Vander Zanden MJ, Fetzer WW (2007) Global patterns of aquatic food chain length. Oikos 116:1378-1388

Vander Zanden MJ, Rasmussen JB (2001) Variation in $\delta^{15} \mathrm{~N}$ and $\delta^{13} \mathrm{C}$ trophic fractionation: implications for aquatic food web studies. Limnol Oceanogr 46:2061-2066

Vanderklift MA, Ponsard S (2003) Sources of variation in consumer diet $\delta^{15} \mathrm{~N}$ enrichment: a meta-analysis. Oecologia 136:169-182

Wada E, Hattori A (1991) Nitrogen in the sea: forms, abundances, and rate processes. CRC Press, Boca Raton

Węsławski JM, Jankowski A, Kwaśniewski S, Swerpel S, Ryg M (1991) Summer hydrology and zooplankton in two Svalbard fiords. Pol Polar Res 12:445-460

Węsławski JM, Kwasniewski S, Stempniewicz L, BłachowiakSamołyk K (2006) Biodiversity and energy transfer to top trophic levels in two contrasting Arctic fjords. Pol Polar Res 27:259-278

Węsławski JM, Kwasniewski S, Stempniewicz L (2009) Warming in the Arctic may result in the negative effects of increased biodiversity. Polarforschung 78:105-108

Węsławski JM, Wiktor J Jr, Kotwicki L (2010a) Increase in biodiversity in the arctic rocky littoral, Sorkappland, Svalbard, after 20 years of climate warming. Mar Biodivers 40:123-130

Węsławski JM, Opanowski A, Legeżyńska J, Maciejewska B, Włodarska-Kowalczuk M, Kędra M (2010b) Hidden diversity in Arctic crustaceans. How many roles can a species play? Pol Polar Res 31:205-216

Węsławski JM, Kendall MA, Włodarska-Kowalczuk M, Iken K, Kędra M, Legezynska J, Sejr M (2011) Climate change effects on Arctic fjord and coastal macrobenthic diversity-observations and predictions. Mar Biodivers 41:71-85

Wheeler A (1992) A list of the common and scientific names of fishes of the British Isles. J Fish Biol 41:1-37

Wildish DJ, Peer D (1981) Tidal current speed and production of benthic macrofauna in the lower Bay of Fundy. Can J Fish Aquat Sci 40:309-321

Winston JE (1978) Polypide morphology and feeding behaviour in marine ectoprocts. Bull Mar Sci 28:1-31

Wu Y, Zhang J, Li DJ, Wei H, Lu RX (2003) Isotope variability of particulate organic matter at the PN section in the East China Sea. Biogeochemistry 65:31-49 